\title{
Cultivar-specific and Non-specific Responses in Tomato Cell Cultures to AL-toxin from Alternaria alternata Tomato Pathotype*
}

\author{
Motoichiro KoDAmA**, Kiyoshi INOUE**, Hiroshi OTANI** \\ and Keisuke Kонмото**
}

Key words : Alternaria alternata tomato pathotype, AL-toxin, tomato callus.

A tomato pathotype of Alternaria alternata $[A$. alternata (Fries) f. sp. lycopersici], which causes stem canker on certain tomato cultivars such as Earlypak 7 in California and First in Japan, produces host-specific AL-toxins (AAL-toxins) ${ }^{4,8}$. The first effects of the toxin on susceptible cells detected by electron microscopy were on mitochondria and rough ER $24 \mathrm{hr}$ after treatment ${ }^{13}$. Gilchrist reported that AL-toxin inhibited the activity of aspartate carbamoyltransferase (ACTase) of susceptible tomato leaves ${ }^{3}$. However, our results $^{7)}$ and those of Fuson and Pratt ${ }^{2)}$ on tomato cell cultures did not support the data that AL-toxin inhibits ACTase. On the other hand, Kawaguchi et al. ${ }^{5)}$ and Orolaza $e t a l .{ }^{11)}$ recently reported the inhibitory effect of the toxin on biosynthesis of phosphatidylethanolamine through ethanolamine in the susceptible leaves.

The use of cultured cells would be expected to have some advantages over intact plant tissues for a study of the mode of action of host-specific toxins (HSTs), because cultured cells are grown synchronously and can be uniformly treated with toxins. We had reported that the host-selective toxicity of AL-toxins was expressed in the cultured cells of tomato as well as the plant tissues ${ }^{7}$. To quantitatively determine the effects of the toxin on cultured cells, a colorimetric assay utilizing a tetrazolium salt, 3-(4,5-dimethylthiazol-2-yl)-2,5-diphenyl tetrazolium bromide (MTT), was employed ${ }^{7,9)}$. This assay method is based on the reduction of MTT to dark blue formazan in active mitochondria in living cells ${ }^{9}$. The amount of the formazan produced by cultured cells, which was proportional to the number of living cells, could be determined precisely by measuring the optical density at $570 \mathrm{~nm}$ of test solution ${ }^{7,9}$. MTT assay seems to be reliable and efficient for examining the effects of AL-toxin on host cells, because the toxin induces ultrastructural damage in the mitochondria in susceptible leaf cells ${ }^{13)}$.

We reported that the toxin selectively affected the viability of cultured cells from susceptible tomato cultivars by using MTT assay ${ }^{7}$. On the other hand, Witsen- boer et $a l^{14)}$ reported that there was no difference in growth of toxin-treated cultured cells between susceptible and resistant cultivars, and they concluded that insensitivity to the toxin was related to a certain level of tomato plant differentiation and was most pronounced in the leaves.

A possible explanation for this discrepancy is that it is due to the different bioassay systems and tomato cell lines employed in these experiments and to occurrence of somaclonal variation during in vitro cell culture. To clarify the differences in toxin action on susceptible and resistant tomato cultured cells, we examined the toxin sensitivity of many cell lines derived from susceptible and resistant tomato cultivars and compared two different assay methods, i.e., determination of cell proliferation and cell viability, for estimating toxin effects on cultured cells. Preliminary results have been published $^{6,12)}$.

Tomato (Lycopersicon esculentum Mill.) cvs. Earlypak 7 and Mie-First, which are susceptible to canker, and cv. Ace, a resistant one, were used. Callus cultures were initiated and maintained as previously described ${ }^{7}$. The calli initiated from 5- to 7-day-old hypocotyls were subcultured once every 3 weeks on Murashige-Skoog (MS) medium supplemented with $0.2 \mathrm{mg} / 1$ 2,4-D and 0.2 $\mathrm{mg} / \mathrm{l}$ kinetin. Nine callus lines of each cultivar, which were subcultured at least 5 times, were cultured for 3 days on MS medium containing AL-toxin I at $2 \mu \mathrm{g} / \mathrm{ml}$, and the viability of each callus line was examined using MTT assay. Heat-treated cells at $100^{\circ} \mathrm{C}$ for 5 min were used as a control of dead cells. MTT assay was modified from the method of Mosmann ${ }^{9}$. Fifty $\mu 1$ of $5 \mathrm{mg} / \mathrm{ml}$ MTT (Sigma) solution was added to each well of a 24-well tray (Falcon) containing $450 \mu 1$ of cell suspension. The trays were incubated for $6 \mathrm{hr}$ at $37^{\circ} \mathrm{C}$. After incubation, cell suspensions were transferred to test tubes and centrifuged at $600 \times g$ for 5 min to collect the cells. To extract the formazan, $3 \mathrm{ml}$ of iso-propyl alcohol was added to each tube, and the tubes were agitated thoroughly. After cell debris was removed by centrifuga-

\footnotetext{
* This work was supported in part by Research Grants Nos. 02304019 and 05404010 from the Ministry of Education, Science and Culture of Japan.

** Faculty of Agriculture, Tottori University, Tottori 680, Japan 鳥取大学農学部
} 
tion at $600 \times g$ for $5 \mathrm{~min}$, absorbance of the extracts was measured at $570 \mathrm{~nm}$ by Hitachi U-2000 spectrophotometer. Figure 1 shows the viability of the toxin-treated cells and control cells incubated without toxin. All toxin-treated cell lines of cvs. Earlypak 7 and Mie-First, which are susceptible to the pathogen, were reduced in their ability to produce MTT-formazan compared with control cells. The viability of Earlypak 7 and Mie-First cells decreased to $13.3 \%$ and $12.8 \%$ on the average, respectively. In contrast, all callus lines of resistant cv. Ace were not affected by the toxin. The results are consistent with a previous report ${ }^{7)}$ indicating that hostselective toxicity of the toxin is expressed in cultured cells as well as the plant tissue. Daub ${ }^{1)}$ reported that responses of cultured cells to HSTs were usually different from that of intact plant tissues because of the mutation of the cells during callus induction. However, AL-toxin sensitivity seems to be maintained stably even in cultured cells.

The difference between the two assay methods, i.e., the MTT assay and the cell proliferation assay, were compared for estimation of toxin effects on cultured tomato cells (Figs. 2 and 3). The calli of susceptible (Mie-First) and resistant (Ace) cultivars were placed on a medium with AL-toxin I added at a concentration of 0.2 and $2 \mu \mathrm{g} / \mathrm{ml}$. After incubation for $6,12,18$ and 24
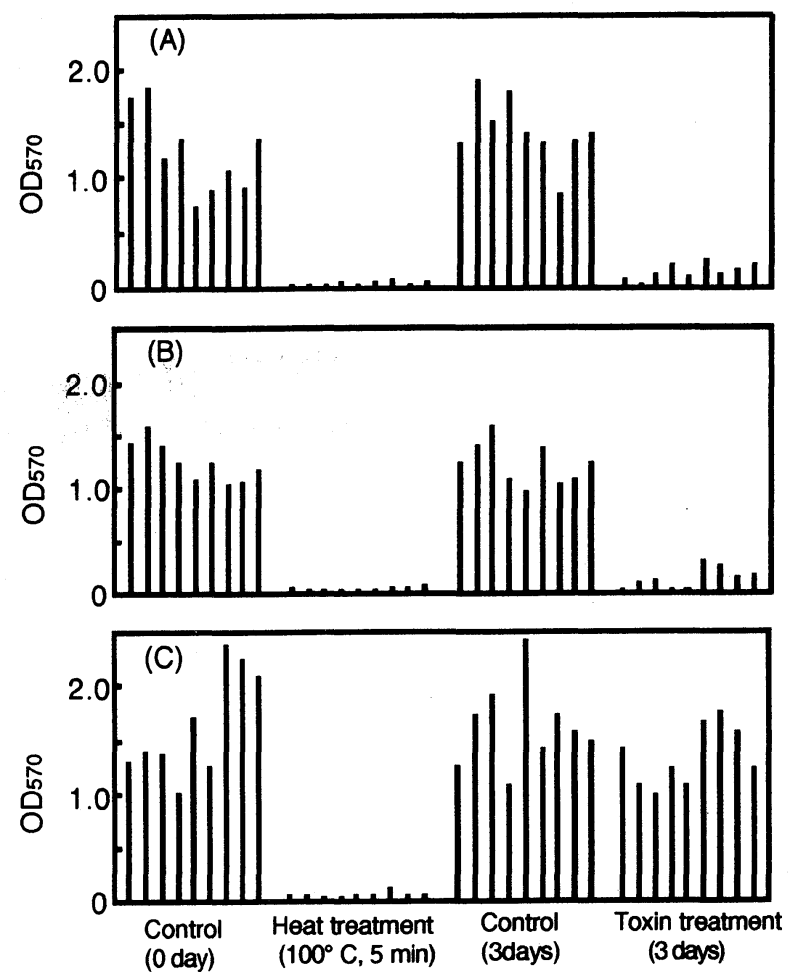

Fig. 1. Effect of AL-toxin I $(2 \mu \mathrm{g} / \mathrm{ml})$ on viability of cultured cells. Nine cell lines each of susceptible cvs. Earlypak 7 (A) and Mie-First (B), and resistant $\mathrm{cv}$. Ace $(\mathrm{C})$ were incubated on MS medium containing the toxin for 3 days at $26^{\circ} \mathrm{C}$. The viability of the cells was measured by MTT assay and is indicated here. Each value represents the average of 5 experiments. days, cell viability was determined by MTT assay (Fig. 2). A decrease in formazan production by susceptible cells treated with the toxin was evident 6 days after toxin exposure. After 12 days of the treatment, the susceptible cells did not have the ability to produce a significant amount of formazan. In contrast, the resistant cells were not affected by the toxin even after 24 days of toxin exposure. Thus, cultivar-specific responses of cultured tomato cells to the toxin were consistent with those of plant tissues.

The effect of the toxin on cell proliferation of cultured cells was also examined (Fig. 3). Tomato suspension cells were cultured with or without the toxin at concentrations of $0.1,0.2,0.5,1.0$ and $2.0 \mu \mathrm{g} / \mathrm{ml}$ in $50 \mathrm{ml}$ of MS medium in a $100 \mathrm{ml}$ flask on a shaker $(120 \mathrm{rpm})$. The packed cell volume of the suspension-cultured cells was measured every 6 days. Cell growth of the susceptible cultivar was completely inhibited at all toxin concentration used (Fig. 3A). In cultured cells of the resistant cultivar, cell growth was also completely inhibited at over $1.0 \mu \mathrm{g} / \mathrm{ml}$ of the toxin (Fig. 3B). At lower concentrations of the toxin, a slight growth of suspension cells was observed after 12 days of incubation. However, no great difference in the influence of the toxin on cell proliferation of cultured cells was observed between susceptible and resistant cultivars. We are presently trying to determine if the inhibitory effect of the toxin on cell proliferation is reversible.

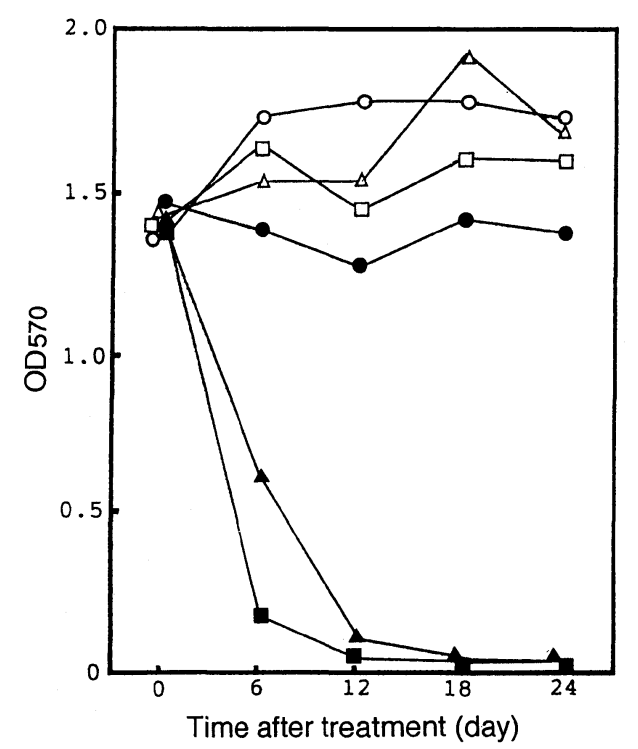

Fig. 2. Viability of cultured cells of susceptible cv. Mie-First and resistant cv. Ace treated with AL-toxin I. Calli of susceptible cv. Mie-First and resistant $\mathrm{cv}$. Ace were incubated on MS medium containing different concentrations (Mie-First; •: 0, $\mathbf{\Delta}: 0.2$, $\mathbf{\square}: 2 \mu \mathrm{g} / \mathrm{ml}$, Ace; $\bigcirc: 0$, $\triangle: 0.2, \square: 2 \mu \mathrm{g} / \mathrm{ml}$ ) of the toxin for indicated periods at $26^{\circ} \mathrm{C}$. After incubation, formazan production by each callus (100 mg fr. wt.) was measured by MTT assay. Each value represents the average of 3 experiments. 


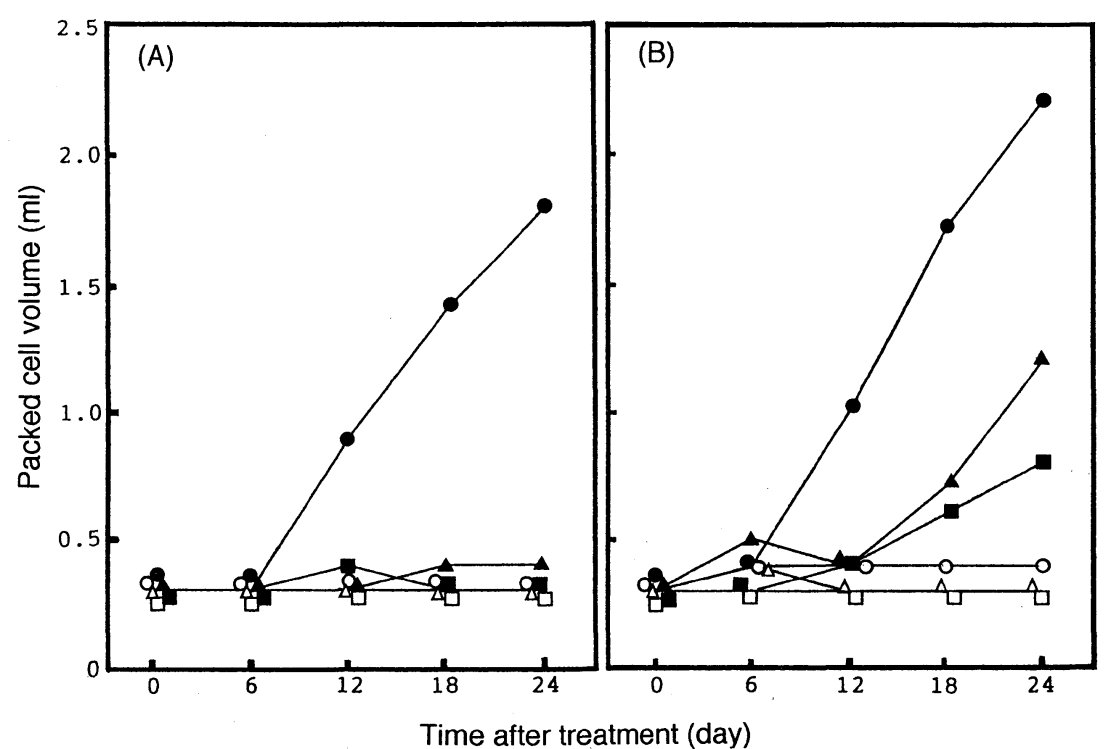

Fig. 3. Effect of AL-toxin on the growth of cultured cells of susceptible cv. Mie-First (A) and resistant cv. Ace (B). Suspension cells were cultured in MS media containing different concentrations of the toxin $(\bullet: 0, \mathbf{\Lambda}: 0.1$, $0.2, \bigcirc: 0.5, \triangle: 1.0, \square: 2.0 \mu \mathrm{g} / \mathrm{ml})$. Packed cell volumes were determined after incubation for the indicated periods at $26^{\circ} \mathrm{C}$. Each value represents the average of 3 experiments.

Witsenboer et $a l .{ }^{14)}$ reported that the toxin inhibited the growth of calli, suspension cells and protoplasts of susceptible and resistant cultivars, although necrosis was never induced in the leaves of the resistant cultivar by the toxin treatment. They concluded that insensitivity to the toxin was related to certain levels of tomato plant differentiation and was most pronounced in the leaves. A non-specific effect of the toxin on cell proliferation of tomato cultured cells was also observed in this study. However, cell viability of the susceptible tomato cultivar was specifically reduced by the toxin, which was determined by MTT assay based on mitochondrial activities of living cells, within 3 to 6 days of toxin exposure ${ }^{7}$. Time course of the viability of toxintreated cells determined by MTT assay was similar to that judged by leaf necrosis assay ${ }^{7,8,14)}$. Orolaza et al. ${ }^{10)}$ recently reported that there was no great difference in the influence of the toxin on the growth of cultured roots between susceptible and resistant cultivars in spite of the root viability of the susceptible cultivar was specifically reduced by the toxin treatment as determined by MTT assay.

These results indicate that AL-toxin non-specifically inhibited the cell growth of both susceptible and resistant cultivars, while only in the susceptible cultivar cell death was specifically induced by the toxin. The difference in toxin sensitivity in tomato leaves, roots and cultured cells seems to be based on the difference in toxin effects judged by various bioassay systems rather than a difference in the differentiation level of the tomato plant. In addition to the specific toxin action on the cell death, AL-toxin may have a common action on both susceptible and resistant tomato cultivars; it might be a factor related to cell division and proliferation. These non-specific action sites of the toxin should be considered in a future study of the toxin receptor in tomato cells. The cultured-cell system will be applicable for selection of toxin-tolerant cells and stem-canker resistant plants.

\section{Literature cited}

1. Daub, M.E. (1986). Tissue culture and the selection of resistance to pathogen. Annu. Rev. Phytopathol. 24: 159-186.

2. Fuson, G.B. and Pratt, D. (1988). Effects of the hostselective toxins of Alternaria alternata f. sp. lycopersici on suspension-cultured tomato cells. Phytopathology 78: 1641-1648.

3. Gilchrist, D.G. (1983). Molecular modes of action. In Toxins and Plant Pathogenesis (Daly, J,M. and Dever. all, B.J. eds.), Academic Press, Sydney, pp. 81-136.

4. Grogan, R.G., Kimble, K.A. and Misagi, I. (1975). A stem canker disease of tomato caused by Alternaria alternata f. sp. lycopersici. Phytopathology 65: 880-886.

5. Kawaguchi, I., Orolaza, N.P.; Tsuge, T., Nishimura, S. and Doke, N. (1991). Changes in amino acid and amine contents of susceptible tomato cultivars infected with Alternaria alternata tomato pathotype or treated with AL-toxin. Ann. Phytopathol. Soc. Jpn. 57: 526-533.

6. Kodama, M., Inoue, K., Otani, H. and Kohmoto, K. (1991). Comparison of the effects of AL-toxin on cultured cells from susceptible and resistant tomato cultivars. Ann. Phytopathol. Soc. Jpn. 57: 417 (Abstr. in Japanese).

7. Kodama, M., Yoshida, T., Otani, H., Kohmoto, K. and Nishimura, S. (1991). Effect of AL-toxin produced by Alternaria alternata tomato pathotype on viability of cultured tomato cells determined by MTT-colorimetric assay. Ann. Phytopathol. Soc. Jpn. 57: 663-670.

8. Kohmoto, K., Verma, V.S., Nishimura, S., Tagami, M. 
and Scheffer, R.P. (1982). New outbreak of Alternaria stem canker of tomato in Japan and production of host-selective toxins by the causal fungus. J. Fac. Agric. Tottori Univ. 17: 1-8.

9. Mosmann, T. (1983). Rapid colorimetric assay for cellular growth and survival: Application to proliferation and cytotoxicity assays. J. Immunol. Methods 65: 55-63.

10. Orolaza, N., Kawaguchi, I., Tsuge, T. and Doke, N. (1992). Effect of AL-toxin produced by Alternaria alternata tomato pathotype on cultured roots of tomato. Ann. Phytopathol. Soc. Jpn. 58: 411-415.

11. Orolaza, N.P., Kawakita, K. and Doke, N. (1992). Inhibitory effect of AL-toxin produced by Alternaria alternata tomato pathotype on the biosynthesis of phosphatidylethanolamine in tomato leaves susceptible to the fungus. Ann. Phytopathol. Soc. Jpn. 58: 719-725.

12. Otani, H., Kodama, M. and Kohmoto, K. (1994). Specific and non-specific actions of AK- and AL-toxins. In Host-Specific Toxin: Biosynthesis, Receptor and Molecular Biology (Kohmoto, K. and Yoder, O.C. eds.), Tottori University, Tottori, pp. 109-118.

13. Park, P., Nishimura, S., Kohmoto, K. and Otani, H. (1981). Comparative effects of host-specific toxins from four pathotypes of Alternaria alternata on ultrastructure of host cells. Ann. Phytopathol. Soc. Jpn. 47: 488-500.
14. Witsenboer, H.M.A., van Schaik, C.E., Bino, R.J., Loffler, H.J.M., Nijkamp, H.J.J. and Hille, J. (1988). Effects of Alternaria alternata f. sp. lycopersici toxins at different levels of tomato plant cell development. Plant Science 56 : 253-260.

$$
\text { 和 文 摘 要 }
$$

児玉基一朗・井上 清・尾谷 浩・甲元啓介：トマト・アル夕 ーナリア茎枯病菌が生成する $\mathrm{AL}$ 毒素に対するトマト培養細胞 の品種特異的および非特異的反応

トマト・アルターナリア茎枯病に感受性の Earlypak 7, 三重 ファーストおよび抵抗性の Ace 各品種由来のカルスそれぞれ 9 系統を $\mathrm{AL}$ 毒素含有培地上で培養した後, 細胞生存率を MTT 法により検定した。その結果, 感受性品種においてのみ, すべて の系統で生存率の低下が認められ, トマト品種の毒素反応性は 培養細胞においても安定に維持されていることが明らかとなっ た。一方, 各品種のカルスを毒素培地上で長期間培養した場合, 培養細胞の増殖は毒素により感受性および抵抗性品種ともに抑 制された。以上の結果より, AL 毒素は感受性品種細胞に対して のみ特異的に細胞死を誘起するが, 細胞増殖の阻害には非特異 的作用を示すことが明らかとなった。

(Received April 17, 1995; Accepted August 14, 1995) 